\title{
Analysis of Staffs' Work Culture at Kabila Sub-District Head Office in Bone Bolango
}

\author{
Zuchri Abdussamad \\ State University of Gorontalo, Indonesia
}

\begin{abstract}
This research aims to analyze: (1) staffs' work cultures at Kabila Sub-district Head Office, (2) factors supporting staffs' work cultures at Kabila Sub-district Head Office, and (3) factors restricting staffs' work cultures at Kabila Sub-district Head Office. This research used primary data collected through interviews from respondents consisting of III and IV officials and representatives of staffs working at Kabila Sub-district Head Office. Additionally, secondary data were also gathered to support primary data, making the data scientifically accountable. Research findings indicated that staffs' work culture at Kabila Sub-district Head Office was good, but some issued should be reconsidered. There were still undisciplined and irresponsible staffs that were incompetent with a low technology understanding level and inadequate service facilities. Government of Kabila and Bone Bolango should immediately socialize the Regent Regulation on Staffs' Work Culture until the level of urban communities (Indonesian: kelurahan). In addition to that, they should also improve the staffs' discipline and give them motivation as well as trainings to enhance their competence as staffs. Finally, they are advised to establish services to support facilities given too.
\end{abstract}

Keywords: Work Culture, Officer

DOI: $10.7176 /$ PPAR/9-4-03

Publication date: April $30^{\text {th }} 2019$

\section{INTRODUCTION}

The national and international development of strategic environment currently faced indicates changes in governance paradigm, institutional system renewal, improvement of human resource competence to establish government and develop the nation, and cooperation among citizens leading to a good governance.

The changes impacts on changes in work cultures that must be faced. Furthermore, a series of adaptation should be conducted on diversity referring to different demographic attributes, such as race, tribe, gender, age, physical status, affiliation, education, or sexual orientation.

Besides diversity, another complex challenge is that how to persuade the staffs to change their old work cultures that does not suit modern work cultures voluntarily. People are doubted to be willing to alter their attitudes based on instructions, but they will when they have gained understanding on it. Unfortunately, such people are little in number, even when their situation has encouraged them to do so.

Further tasks of governance and development will closely relate to the national value stating that each social community and tribe has their own work culture. As the consequence, the work culture will either support or impede staffs' performances. According to the Decree of the Ministry of Administrative and Bureaucratic Reform Number 25/KEP/M.PAN/4/2002 on Guidelines for the Development of the Work Culture of State Apparatuses, work culture is the attitude and behavior of individuals working as the state apparatuses in accordance with trusted values that become their working characteristics and natures applied in their daily life.

Work culture constitutes all behaviors of state apparatuses that become their habits. It does not suddenly appear, but should be attempted to form a good and accountable work culture through a controlled process involving all human resources ruled by a series of systems.

Quality of work culture closely links to an organizational culture, in that we can observe the staffs' performances and behaviors. Law Number 43 Year 1999 Article 13 (1) on Civil Servant Management was issued to ensure the implementation of government and development tasks effectively and efficiently. Furthermore, Law Number 43 Year 1999 Article 13 (2) mentions that to establish the tasks prompted by Paragraph (1), professional, responsible, honest, and just civil servants trained based on work achievement and carrier systems focused on work achievement systems are required.

To create competent apparatuses, the government implement some operational functions; such as giving trainings to support the staffs' performances, establishing a good work culture. The development of work culture is also investigated by the staffs' work culture manifesting their real condition in field; such as their attitudes on their duties and behaviors while working. Subsequently, the Ministry of Administrative and Bureaucratic Reform issued the Decree of the Ministry of Administrative and Bureaucratic Reform Number 25/KEP/M.PAN/4/2002 on Guidelines for the Development of the Work Culture of State Apparatuses concentrating on the attitude and behavior of individuals working as the state apparatuses in accordance with trusted values that become their working characteristics and natures applied in their daily life. 


\section{LITERARY REVIEW}

Administrative science is a product of human thinking and reasoning rationally and systematically compiled that reveals clarity of formal object. Such thinking and reasoning aims to create regularity of various actions and reactions performed by human and other material objects, i.e. those that conduct administrative activities in form of cooperation to realize a certain goal (H. Makmur, 2007:5-6). Fundamental essence of administrative formal and material objects is the relationship between the regulators and regulated within a cooperation context among men.

As argued by Waldo (1995) in Faried Ali and Baharudin (2014:5), the early concept of administration was cooperation among men that was established by rational consideration to achieve goals. It was due to a rational that there were various activities that might occur and or were held by men under a cooperation that could not be conceptualized as administration.

\subsection{Public Administration}

Public administration is engaged to the implementation of state governance. Hence, public administration is the government activity. Guzman, as quoted by Leveriza (1990) in LAN (2008:1) believes that public administration is "government in action". Then, Guzman in LAN (2008:1) also confirms that "when there is a government, there is also public administration." Public administration embodies cooperation activities by human to realize the government goals.

Chandler and Plano, in Pasolong (2010:7) clarify that public administration is a process where public resources and personnel are organized and coordinated to formulate, implement, and manage decisions in public policies. Chandler and Plano convey that public administration is both art and science to regulate and implement any determined tasks. Public administration as a scientific discipline functions to solve public problems through improvements, especially in fields of organization, human resources, and finance. Marshall E. Dimock, Gladys O. Dimock, and Louis W. Koening, in Pasolong (2010:7) explain that public administration includes (1) implementation of the government policy stipulated by political representative agencies, (2) individual and communal work coordination, i.e. daily tasks of the government, and (3) processes involving the implementation of the government policies, uncountable direction of skills and techniques, and direction and intention towards a certain group's works. Referring to aforementioned definitions of public administration above, public administration is a cooperation by a group of people or institution to implement the state governance, complying with public rights effectively and efficiently.

\subsection{Work Culture}

Budaya, or culture, was derived from the Sanskirt word 'budhayah', a plural form of budhi defined as logic or any matter related to mind, values, and mental attitudes (Decree of the Ministry of Administrative and Bureaucratic Reform Number 25/KEP/M.PAN/4/2002). Budidaya, or cultivation, means cultivate budhi. In English, the phenomenon is called 'culture' (Latin: cotere). In its early development, the word was defined as to cultivate or do something (cultivate a farm land) and developed into a human way to actualize values, creativity, and performances. Furthermore, budidaya also constitutes the whole spiritual and material attempts including potencies and skills of a community or group. Culture is social, as human generates their material tradition to the future generation historically and based on the applicable "values". The intended values are the highest standard for human behaviors.

Slocum (1995), in West (2000:128) declares culture as basic assumptions and meaning pattern that are supposed to be complied and manifested by all parties participating in an organization. Culture is also defined as a set of behaviors, emotions, and psychological frameworks deeply internalized and belonging to members of Osborn and Plastrik organizations (2000:252). Consequently, to change a culture means to change the old paradigm applied. Meanwhile, Sofo (2003:384) depicts culture as a matter referring to values, beliefs, practices, rites, and nature of an organization that also forms behaviors and customizes perceptions.

Newstrom and Davis, in Widyo Y. Prayitno (2004:12) state that culture significantly supports a successful working unit by giving the staffs identity; acting as a stability and continuity sources for an organization, securing them; and stimulating them to be enthusiastic about their works. Furthermore, the fundamental goal of culture is to manifest a whole human resource, giving them awareness of their roles as a supplying customer in a communication with others effectively and efficiently (Triguno, 2004:6).

Work is simply defined as any human activity demanding their bio-psycho-spiritual energy, aiming to gain a certain output (Sinamo, J.H., 2002:43). Hasibuan (2000:47) argues that work is to sacrifice service, physic, and mind to generate materials or services by deriving rewards upon a certain achievement. Work should also be defined as human's noble activities, since it does not only mean their survival attempt, but also their realization towards nature. Therefore, work constitutes self-realization as well (Puspowardjojo, 1985:116).

Work culture is a philosophy based on several views that becomes values manifesting encouraging nature, habit, or power. It is cultivated into a community or organization that is reflected as behaviors, beliefs, goals, 
opinions, or acts manifested as "work or working" (Triguno (in Prasetya, 2001:12). Therefore, each work function or process should be diverse in terms of the working method. However, in consequent, values taken as the organization framework will be different too. Values, behaviors, and work culture are continuous processes.

\subsection{Research Method}

The research method was the descriptive method, aiming to obtain and deliver facts clearly. A descriptive study should be thorough and compact, focusing on indicating which was significant and insignificant. The grounded research concept clarified that qualitative research was significant by proposing a different view on the relationship between theory and observation.

Meanwhile, data analysis technique used in this research was the inductive one, an analysis based on specific evidence that then produced a general conclusion. Finally, all arguments or information from data obtained by interviews were reinforced by the results of documentation and observation and generally concluded.

Steps conducted by the researcher to analyze the data were data reduction, data presentation, conclusion drawing, and verification.

\section{FINDINGS AND DISCUSSION}

There were five work cultures applied by staffs at Kabila Sub-district Head Office in accordance with the Regent Regulation of Bone Number 11 Year 2013 on Work Culture:

\section{Fast Service}

Fast service means quick response, or willingness to help and give a quick and proper service, clear information, and time certainty to finish a certain type of service to people.

The head of general service division confirmed that quick service mentioned in the Regent Regulation Number 11 Year 2013 on Work Culture had been applied by all staffs/apparatuses at Kabila Sub-district Head Office. However, there were always principle services that should be managed by the sub-district head himself and could not be delegated to any other services, hence requesting managing time.

\section{Easy Service}

Easy service is easiness to connect to any service officials or staffs, including easiness to get clear information.

The head of governance division at Kabila Sub-district Head Office (IA) conveyed that easy service suggested by the Regent Regulation Number 11 Year 2013 on Staffs' Work Culture had not been completely implemented, because there were still stages that should have been conducted. Additionally, the sub-district head as the land title registrar was absent due to his tight schedule outside.

\section{Hospitality}

Hospitality should be accompanied by empathy, a sincere and individual attention from the service provider that also always managed to understand people's desires.

The head of office planning division at Kabila Sub-district Head Office (VR), hospitality in accordance with the Regent Regulation Number 11 Year 2013 on Staffs' Work Culture had not been thoroughly implemented. Because hospitality greatly depended on each individual, its absence was mainly due to the individual characters and personalities.

\section{Reliable Service}

Reliable means to suit to what had been promised. Reliability could be due to assurance by having skillful staffs and sophisticated facilities, and thus providing assurance to people.

One of the staffs of the law and order division conveyed that reliable service referring to the Regent Regulation Number 11 Year 2013 on Staffs' Work Culture had not been well implemented at Kabila Subdistrict Head Office. There were still several unskilled and incompetent staffs. Reliable service might be restricted by insufficient supporting facilities for the service.

\section{Civilized Service}

Being civilized means being in accordance with customs.

The secretary of Kabila (US) declared that civilized service in accordance with the Regent Regulation Number 11 Year 2013 on Staffs' Work Culture had been applied and implemented by all staffs at Kabila Subdistrict Head Office.

\section{Discussion}

\section{Staffs' Work Culture at Kabila Sub-district Head Office}

Quick service: Quick service had been provided by staffs at Kabila Sub-district Head Office long before the Regent Regulation on Staffs' Work Culture was issued. The fact was concluded through results of interviews done by the researcher to one of the staffs at Kabila Sub-district Head Office. Moreover, principle issues could not be delegated to one of the officials at the government of Kabila. For example, land notarial sale and purchase agreement should be signed by the sub-district head that also acted as the land title registrar; provision of 
business permit recommendation and other important subjects still demanded field review process, prolonging time for the service process; and before signed, land title registrar should be verified until the village-sub-village level.

Easy service: Service provided by staffs at Kabila Sub-district Head Office was still difficult to get, as several important matters related to information acquisition for the society could not be directly given. For instance, accurate information on time certainty of the salary reimbursement for imams, Syara staffs, teachers, and sub-village heads still lacked. The information should be delivered by the sub-district head due to its potential to arise conflicts. Furthermore, other necessary information and consultation directly linked to any accountability, duties, and activities of each division and sub-division were delivered by the heads themselves. It occurred due to the absence of officials because of their activities.

Hospitality: One of the staffs at Kabila Sub-district Head Office argued that hospitality had been provided by the staffs. However, there were still those that did not show any hospitality due to their characters and personalities.

Reliable service: Reliable service had not been well implemented by all staffs at Kabila Sub-district Head Office, because there were still unskillful and incompetent staffs. Another challenge in such service provision was the lack of supporting service facilities that was not in accordance with the standard operational procedures.

Civilized service: One of the staffs at Kabila Sub-district Head Office clarified that civilized serviced had been long implemented before the Regent Regulation on Staffs' Work Culture was issued, since tradition referring to syara in accordance with kitabullah was the motto of Gorontalo society, and Bone Bolango was one of the daerah adat in Gorontalo.

\section{Supporting Factors of Staffs' Work Culture at Kabila Sub-district Head Office Working Motto}

a. Smile

Research findings indicated that as one of the working mottos, smile had been always made by staffs at Kabila Sub-district Head Office. In all occasions, the regent of Bone Bolango as the staff supervisor always encourage the staffs to smile while giving service.

\section{b. Address}

Meanwhile, another working motto, addressing was also implemented by all staffs at Kabila Sub-district Head Office. They addressed their partners as well as the society.

\section{c. Greet}

The last motto, greeting was always performed by all staffs at Kabila Sub-district Head Office.

\section{Principles of Work Relation}

a. To teach: Research findings revealed that to teach, one of the principles of work relation had not been implemented by all staffs at Kabila Sub-district Head Office. However, most of them had held willingness to do.

b. To love: Research findings also proposed that to love was included as one of the principles of work relation. At Kabila Sub-district Head Office, it had been well implemented by the staffs. The staffs admitted that establishing communication might encourage them to complete their duties at the office.

c. To take care: Another finding was that to take care, the last principles of work relation had also been implemented by all staffs at Kabila Sub-district Head Office. Most staffs had created an emotional bond, uniting them as a family. Therefore, any miscommunication among them could be immediately solved privately.

\section{Factors Restricting Staffs' Work Culture at Kabila Sub-district Head Office}

The factors were staffs' indiscipline, lack of awareness and responsibility, low education level, lack of competence, and low technology competence.

a. Indiscipline: Research findings indicated that there were still undisciplined staffs at Kabila Sub-district Head Office, in terms of either punctuality or duties. However, such staffs came in few numbers, about 10-15\%. Regardless the number, it would impact on easy service provision, such as easy access to service officials or staffs to obtain clear information and quick service provision. Hasibuan (2005:193) argued that discipline was the most important operative function of human resource management. The more discipline the staffs, the higher their achievement. Without discipline staffs, an organization would meet difficulties to create optimum outputs. Discipline reflected the staffs' responsibility on their duties.

b. Lack of awareness and responsibility as a staff: Another research finding suggested that staffs at Kabila Subdistrict Head Office had not been fully aware of their responsibility as a staff/apparatus. Few staffs, around $10-15 \%$ at percentage, were present for only checking their presence list and then went away. It definitely restricted the quick service provision, that staffs should provide friendly service to the society and understand their intention. The responsibility was regulated by the Decree of the Minister of Administrative and Bureaucratic Reform Number 63 Year 2003 on General Guidelines for the Implementation of Public Service, 
particularly in the session stating the principles of public service. In it, the appointed officials should be responsible for the implementation of service and problem solving regarding public services. The same focus was regulated in the Decree of the Minister of Administrative and Bureaucratic Reform Number 25 Year 2004 on Guidelines for Compiling Community Satisfaction Index at the Instance Service Unit, emphasizing that staffs should be responsible for their duties in the service implementation and problem-solving.

c. Low education level and lack of competence: Table 4.3 shows that $44.5 \%$ of staffs at Kabila Sub-district Head Office had only completed their senior high school degree. Nevertheless, it did not impact on service and administrative activities at the office. Work system implemented at the office was complementary. When there was a staff unable to do a certain task, the head of division or sub-division or other staffs would help him/her. Meanwhile, Table 4.5 suggests that the staffs still lacked competence, indicated by their education level and III and IV leadership trainings. There was only one staff that had participated in the III leadership training and IV leadership training; whereas other 25 staffs, $92.6 \%$, never participated in both leadership trainings. Hence, another education, training, technical guidance, or trainings improving the staff competence were necessary. The lack of competence might disturb quick service provision, as staffs were expected to give such service. Furthermore, it might also impede reliable service, because the staffs should be skillful and competent in giving the service to the society. Michael Amstrong, in Sudarmanto (2014:46) believed that competence was what people characterized in a work in different types and levels of behaviors. Competence determined aspects of work performance process. Moreover, Brian E. Becher, Mark Huslid, and Dave Ulrich, in Sudarmanto (2014:47) defined competence as individual knowledge on skill, ability, or characteristic directly affecting their work performance.

d. Low technology competence: Research findings indicated that most staffs at Kabila Sub-district Head Office had mastered and been familiar with technology. However, after interviewing the informants, the researcher was aware that there were $5-10 \%$ of staffs that were incompetent in terms of the use of technology. Lack of supporting facilities at the office was assumed to be one of the causes. Additionally, the incompetence might restrict reliable service provision, since staffs were supposed to be skillful and competent in working and giving services, ensuring the society. Parasuraman and Zeithami, in Rakhmat (2009:108) added that service quality should be supported by physical facilities, equipment, infrastructures, or staffs provided by organization.

\section{CLOSING}

\subsection{Conclusion}

Based on the results of analysis and field research on staffs' work culture at Kabila Sub-district Head Office

Bone Bolango, the researcher drew conclusions as follows:

1. Five staffs' work cultures at Kabila Sub-district Head Office in accordance with the Regent Regulation of Bone Bolango Number 11 Year 2013 on Staffs' Work Culture in the Government of Bone Bolango had been well implemented, but there were still several principle issues that should be reviewed, hence prolonging the service process. Some staffs were reportedly unfriendly and incompetent. Furthermore, there were still inadequate supporting service facilities.

2. Several supporting factors of work culture at Kabila Sub-district Head Office were working mottos consisting of to smile, address, and greet as well as principles of work relation containing three principles, i.e. to teach, love, and take care. The mottos and principles had been long implemented by the staffs at Kabila Sub-district Head Office.

3. Factors restricting staffs' work culture at Kabila Sub-district Head Office were staffs' indiscipline, lack of awareness and responsibility, low education level, lack of competence, and low technology competence.

\subsection{Suggestions}

1. Socialization regarding the Regent Regulation of Bone Bolango Number 11 Year 2013 on Staffs' Work Culture in the Regional Government of Bone Bolango, from the upper to low levels (urban communities) should be performed by the Division of Law and Organization of the Regional Secretariat of Bone Bolango or the Regional Board of Employment, Education, and Training of Bone Bolango.

2. Discipline should be enforced to all staffs and heads, and motivation should be given to all staffs by the heads.

3. Education and trainings or technical guidance are given to improve staffs' competence, and supporting service facilities should be upgraded too.

\section{REFERENCES}

Faried Ali and Baharudin. (2014), Ilmu Administrasi dalam Pendekatan Hakikat Inti, Refika Aditama, Bandung. Hasibuan, SP, (2000). Manajemen Sumber Daya Manusia, Ed Revisi, PT. Bumi Aksara, Jakarta

\section{(2005). Manajemen Sumber Daya Manusia. PT. Bumi Aksara Jakarta}

H. Makmur, (2007) Filsafat Adminisrasi, Bumi Aksara, Jakarta, 
Osborn, D and Peter P, (2000), Memangkas Birokrasi, Ed Revisi, PPM, Jakarta.

Pasolong Harbani. (2010), Teori Administrasi Publik, Alfabeta Bandung.

Prasetya, Buletin (2001). Mengenal Program Budaya Kerja, No. 01, January. Surabaya.

Puspowardojo S, (1985). Strategi Kebudayaan, PT. Gramedia. Jakarta.

Rakhmat. (2009). Teori Administrasi dan Manajemen Publik. Pustaka Arif: Jakarta

Sinamo, Jansen H, (2002). Etos Kerja 21 Etos Kerja Profesional di Era Digital Global, $1^{\text {st }}$ ed., Institut Darma Mahardika. Jakarta,

Sofo F. (2003). Pengembangan Sumber Daya Manusia, $1^{\text {st }}$ ed., Airlangga University Press. Surabaya.

Sudarmanto. (2014). Kinerja dan Pengembangan Kompetensi SDM, Pustaka Pelajar: Yogyakarta.

Triguno, (2004). Budaya Kerja: Menciptakan Lingkungan Yang Kondusive Untuk Meningkatkan Produktivitas Kerja, $6^{\text {th }}$ ed., PT. Golden Terayon Press. Jakarta.

West, M.A., (2000). Mengembangkan Kreativitas dalam Organisasi, $1^{\text {st }}$ ed., Kanisius. Yogyakarta.

Widyo Yudo Prayitno, (2004), Budaya Kerja, Kemampuan, dan Komitmen Pegawai Negeri Sipil. Studi Kasus Biro Kepegawaian Sekretariat Daerah Provinsi Jawa Timur.

\section{Documents}

Decree of the Ministry of Administrative and Bureaucratic Reform of the Republic of Indonesia Number 25/KEP/M.PAN/4/2002 on Guidelines for the Development of the Work Culture of State Apparatuses, Jakarta.

Attachment of the Decree of the Minister of Administrative and Bureaucratic Reform Number 63 Year 2003 on General Guidelines for the Implementation of Public Service.

State Administrative Agency 2008, Modul Pendidikan dan Pelatihan Kepemimpinan Tingkat IV, Dasar-dasar Administrasi Publik. State Administrative Agency, Makassar.

Regent Regulation of Bone Number 11 Year 2013 on Civil Servants' Work Culture in the Government of Bone Bolango, Suwawa.

Law of the Republic of Indonesia Number 43 Year 1999 on Amendment of the Law Number 8 Year 1974 on Basic Law on Civil Service. 